\title{
Genetic and epigenetic factors in regulation of microRNA in colorectal cancers
}

\author{
Serena Vinci, Stefania Gelmini, Irene Mancini, Francesca Malentacchi, Mario Pazzagli, Cristina Beltrami, \\ Pamela Pinzani, Claudio Orlando*
}

Clinical Biochemistry, Dept. of Clinical Physiopathology, University of Florence, Italy

\section{A R T I C L E I N F O}

\section{Article history:}

Available online 16 September 2012

Communicated by Michael W. Pfaffl

\section{Keywords:}

MicroRNA

Single nucleotide polymorphisms

High Resolution Melting

Methylation

\begin{abstract}
A B S T R A C T
Studies on miRNA profiling revealed that a large number of them are significantly deregulated in human cancers. The molecular mechanisms of this deregulation are not totally clarified, even if genetics and epigenetics are frequently involved.

Single nucleotide polymorphisms (SNPs) are the most common type of genetic variation in the human genome. A SNP into miRNA gene might affect the transcription of primary miRNA, its processing and miRNA-mRNA interaction. We investigated the distribution of sequence variants of miR-146a, miR-196a2, miR-499 and miR-149 in colorectal cancer (CRC) and their effect on miRNA expression. Each variant was identified with HRM. For miR-499 we demonstrated a significant reduction of its expression in CRC connected to a specific genotype.

To evaluate the epigenetic effects on miRNA genes in CRC, we investigated the influence of DNA methylation on miR-34b, miR-34c and miR-9-1 expression. We aimed to verify the relationship between the methylation status of these miRNA genes and their relative expression in tumor samples. For the quantification of DNA methylation we adopted a method based on Differential High Resolution Melting (D-HRM).
\end{abstract}

(C) 2012 Elsevier Inc. All rights reserved.

\section{Introduction}

MicroRNAs (miRNAs) are a class of 21-25 nt single-stranded non-coding RNAs that regulate gene expression at a posttranscriptional level. MiRNAs are transcribed as long primary transcripts (pri-miRNAs) which are processed in the nucleus into hairpin-shaped precursor miRNAs (pre-miRNAs) by a nuclear complex consisting of a member of the ribonuclease III family (RNase III) Drosha and its cofactors (DGCR8) [1,2]. Pre-miRNAs are exported to the cytoplasm by Exportin-5 [3,4] and then processed into $18-25$ nt long mature miRNAs by RNA Dicer, which is part of the RISC RNA-induced silencing complexes to repress gene expression [5,6]. The mature miRNA leads RISC to regions of partial complementarity in the 3'UTR of target mRNA and triggers either their degradation or inhibition of translation [7]. Perfect or almost perfect complementarity to target results in the RISC-mediated mRNA degradation, whereas the presence of few mismatched bases is thought to arrest translation of the mRNA by the ribosome [8].

It is assessed that there may be 1000 miRNA genes in human genome [8-10] and that a single miRNA can bind hundreds of mRNA targets, even if their identification is difficult because only

\footnotetext{
* Corresponding author. Address: Clinical Biochemistry, Dept. of Clinical Physiopathology, viale Pieraccini 6, 50139 Florence, Italy. Fax: +39 0554271371.

E-mail address: c.orlando@dfc.unifi.it (C. Orlando).
}

the seed sequence (about $6-8$ bases) aligns with the target mRNA $3^{\prime}$ untranslated region [11,12].

Many evidences indicate that miRNAs are involved in malignant transformation of human cells [7] and miRNA profiling is significantly altered in human cancer [3,9,13]. Deregulation of miRNA expression seems to generate an important signaling cascade, since most of them have a large number of potential mRNA targets.

Sequence variants in miRNA genes are described as mechanisms that can contribute to their deregulation [14]. A mutation or a SNP at a miRNA region might affect the transcription of miRNA primary transcripts, their processing to mature miRNA or miRNA target interactions $[3,15]$. Whereas most of the identified mutations or SNPs in miRNA do not affect miRNA expression and function [3,14,16-18], in some cases SNPs are associated with loss or reduction of miRNA expression [3].

Recently, a large number of potentially functional miRNArelated SNPs were identified and proposed as candidate cancer biomarkers. In this study we investigated the distribution of sequence variants of miR-146a, miR-196a2, miR-499, miR-149, in colorectal cancer (CRC).

In different studies were highlighted several associations between one or more SNPs of these mRNA and cancers [19-22].

In our previous work on these four miRNAs, we found an increased risk for NSCLC, presumably through an association with increased miRNA expression and CG genotype of miR-146a and we 
Table 1

Characteristics of patients affected by CRC.

\begin{tabular}{lc}
\hline Median age (range) & $69(39-89)$ \\
Gender & yrs \\
Males & 87 \\
Females & 73 \\
Stage & \\
Duke's 1 & 20 \\
Duke's 2 & 74 \\
Duke's 3 & 53 \\
Duke's 4 & 13 \\
Localization & \\
Cecum, Ascending Transverse, Sigmoid, Descending, & 59 \\
Rectum & \\
& 101 \\
Grading & \\
G1 & 20 \\
G2 & 124 \\
G3 & 16 \\
\hline
\end{tabular}

confirmed that miRNA-196a2 is upregulated in NSCLC patients but in an independent manner from the genotype [23].

In this paper we analyzed the distribution of the above mentioned polymorphic variants in patients affected by colorectal cancer (CRC) and possible relationships between miRNA genotypes and expression.

Each variant was detected with HRM, while the relationship with miRNA expression profile was evaluated with dedicated real time RT-PCR assays.

Concerning the epigenetic mechanisms influencing miRNA expression, we know that one-third of all human miRNA genes has a CpG island in the upstream region and may be regulated by DNA methylation [24]. In colorectal cancer several miRNAs were found silenced by comparing primary colorectal cancers with matched normal colorectal epithelium [25]. In particular miR-1292, miR-9-1, and miR-137 were found silenced by DNA methylation in cancer [26]. Toyota et al. treated HCT116 colorectal cancer cells with the demethylating agent, 5-aza-2'-deoxycytidine (5-aza-dC), and compared miRNA expression profiles between the treated

Table 2

Primers and experimental procedures for miRNA genotyping.

\begin{tabular}{|c|c|c|c|c|}
\hline SNP & Primers forward & Primers reverse & Annealing temperature $\mathrm{PCR}\left({ }^{\circ} \mathrm{C}\right)$ & Range of temperature $\operatorname{HRM}\left({ }^{\circ} \mathrm{C}\right)$ \\
\hline miR-146a (rs2910164 C-G) & GGGTCTTTGCACCATCTCTG & TCCAGTCTTCCAAGCTCTTCA & 57 & $77-87$ \\
\hline miR-149 (rs2292832 C-T) & GTGTCTTCACTCCCGTGCTT & АССТСТСАСАСССССТСАС & 58 & $88-98$ \\
\hline miR-196a2 (rs11614913 C-T) & TCCTCCAGATAGATGCAAAGC & GAGGGTAGGAGTGGGAGAGG & 60 & $80-90$ \\
\hline miR-499 (rs3746444 G-A) & CGGCTGTTAAGACTTGCAGTG & САССССТТССССАСАААС & 59 & $80-90$ \\
\hline $\mathrm{miR}-34 \mathrm{~b} / \mathrm{c}$ & GGTTGGGAATTGAAGTTTG & CCСAAAAATACСAAACCT & 55 & $75-95$ \\
\hline miR-9-1 & GTTTTTTTTATTTGGGATTAG & ACAACAACAAAAACCTCAAAC & 57 & $70-90$ \\
\hline
\end{tabular}

\section{D-HRM miR-9-1}
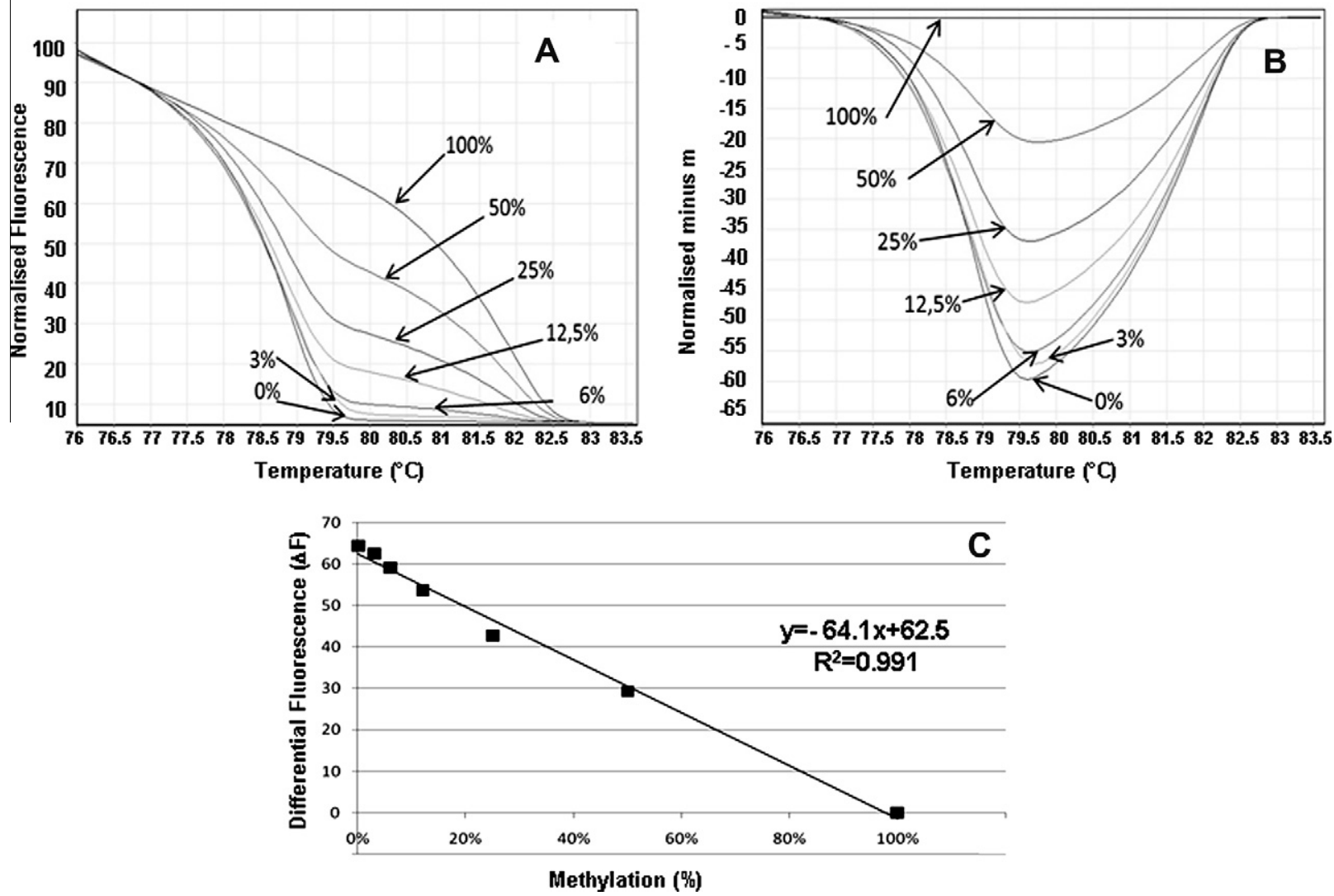

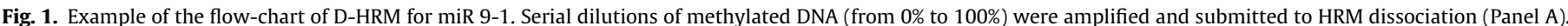

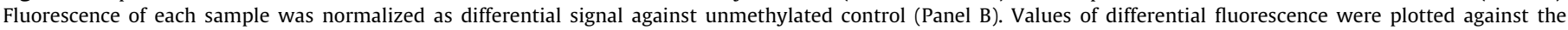
concentration (\%) of each dilution to generate a standard curve (Panel C). 
and the untreated cells to identify silencing of miR-34b/c by promoter DNA hypermethylation [27].

Even if the relationship between promoter hypermethylation and miRNA silencing was proved by these experiments, a direct 'in vivo' relationship between the density of methylation of these miRNAs and their relative expression in tumor samples was not previously demonstrated. To this purpose we developed a method allowing the measurement of DNA methylation based on D-HRM [28]. We evaluated in our CRC samples the potential influence of DNA methylation of miR-34b, miR-34c and miR-9-1 on their expression.

\section{Materials and methods}

\subsection{Tissues and blood samples}

CRC samples were collected from 160 patients (Table 1). During surgical resection of colorectal cancers (CRC), one sample of tumor tissue and the corresponding apparently normal mucosa were retrieved from each patient. Control tissues were taken $10 \mathrm{~cm}$ apart from the neoplasia. In all cases comparable tissue samples were processed for routine histological examination. Tissue samples were immediately steeped in RNAlater (Qiagen Gmbh, Hilden, Germany) at $4{ }^{\circ} \mathrm{C}$ for $24 \mathrm{~h}$ and subsequently stored at- $80^{\circ} \mathrm{C}$ until analysis. Tissues were disrupted by TissueLyser with Stainless Steel Beads $5 \mathrm{~mm}$ (Qiagen) according to the manufacturer's instructions. DNA purification was performed with QIAcube ${ }^{\mathrm{TM}}$ and QIAamp DNA mini Kit (Qiagen). For miRNA extraction we used mirVana ${ }^{\mathrm{TM}}$ miRNA Isolation kit (Ambion, Life Technologies, USA) according to the manufacturer's protocol. The concentration of DNA and total RNA was determined with Nanodrop ND-1000 Spectrophotometer (Thermo Scientific, DE, USA).

To compare allele distribution in the control population, we collected a blood sample from 178 subjects without any evidence of diseases, matched for sex and age with CRC patients. DNA was extracted from nucleated cells with QIAamp DNA Blood Mini kit (Qiagen).

The study protocol was approved by the local Ethical Committee and informed consent was obtained from all patients and healthy volunteers.

\subsection{Real-time RT-PCR measurement of miRNA expression}

To measure miRNA expression, 10 ng total RNA were reverse transcribed with TaqMan Reverse Transcription Kit and assayed by the respective TaqMan microRNA kit (miR-146a ID 000468; miR-149 ID 000472; miR-196a2 ID 000495; miR-499 ID 001045; miR-9-1 ID 000583; miR-34b ID 002102; miR-34c ID 000428; Applied Biosystems, Life Technologies, USA) according to manufacturer's instructions. For Real-Time PCR we used an ABI PRISM 7900HT Fast PCR System (Applied Biosystems). The miR-U6B was used as endogenous control, as already reported [29,30].

\subsection{HRM for genotype identification}

We evaluated allelic distribution of sequence variants in premiRNA hsa-miR-146a (rs2910164 C-G); hsa-miR-149 (rs2292832 C-T); hsa-miR-196a2 (rs11614913 C-T) and hsa-miR-499

\section{D-HRM miR-34b/c}
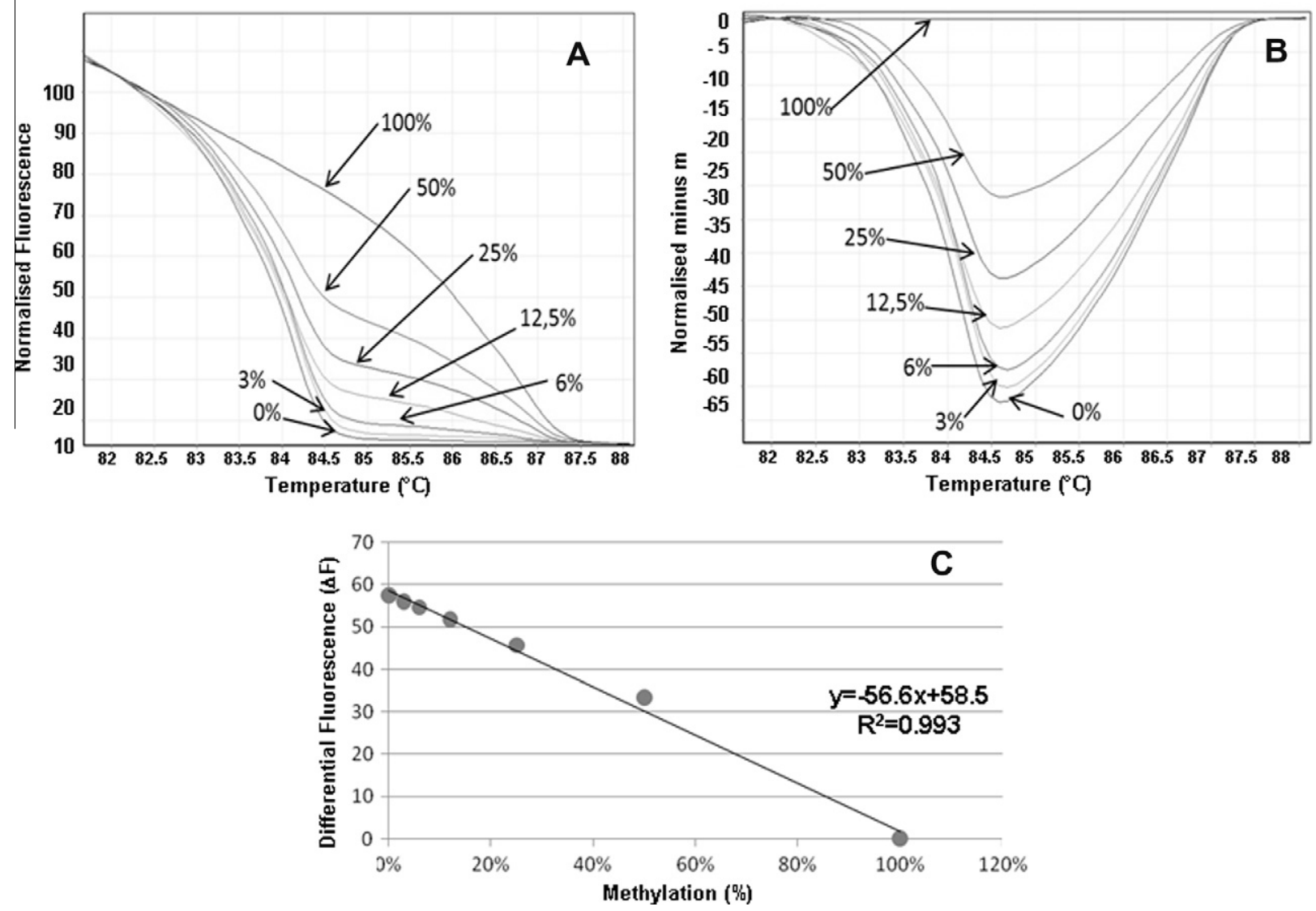

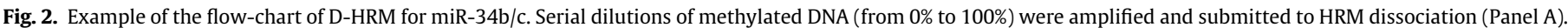

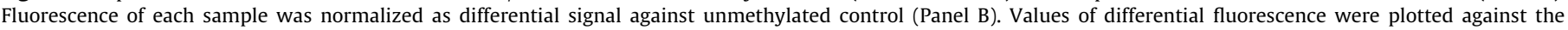
concentration (\%) of each dilution to generate a standard curve (Panel C). 
(rs3746444 G-A) in tissue biopsies collected from 160 patients affected by CRC and in control subjects, using HRM. We amplified $100 \mathrm{ng}$ DNA in a $25 \mu \mathrm{L}$ final volume, containing $10 \times$ Buffer, $1.5 \mathrm{mM} \mathrm{MgCl} 2,800 \mu \mathrm{M}$ dNTPs, $300 \mathrm{nM}$ of each primer, $1.5 \mu \mathrm{M}$ of SYTO9 Dye (Invitrogen, Carlsbad, CA, USA) and 1U of Taq Gold Polymerase (Applied Biosystems). PCR was performed with an initial step at $95{ }^{\circ} \mathrm{C}$ for $10 \mathrm{~min}$, followed by 35 cycles for $30 \mathrm{~s}$ at $95^{\circ} \mathrm{C}$, $30 \mathrm{~s}$ at the respective annealing temperatures (Table 2) and $30 \mathrm{~s}$ at $72{ }^{\circ} \mathrm{C}$, with a final extension at $72{ }^{\circ} \mathrm{C}$ for $20 \mathrm{~min}$. For HRM, samples were initially maintained for $5 \mathrm{~min}$ at $95^{\circ} \mathrm{C}$ and $1 \mathrm{~min}$ at $40^{\circ} \mathrm{C}$ and then submitted to specific melting profiles (Table 2 ) on a RotorGene 6000 (Corbett Research, Australia). Primers for HRM were selected using Primer 3 software [31].
To confirm HRM results, sequencing analysis was performed in $10 \%$ randomly selected samples. In these cases, after HRM, samples were purified with a PCR Purification Kit (Qiagen) and submitted to cycle sequencing with $2 \mu \mathrm{L}$ of BigDye Terminator Ready Reaction Mix (Applied Biosystems), $2 \mu \mathrm{L}$ of sequencing buffer and the same primers used in HRM but $0.8 \mu \mathrm{M}$ in a final volume of $10 \mu \mathrm{L}$. After purification with a DyeEx 2.0 Spin Kit (Qiagen), samples were analyzed with the ABI Prism 310 Genetic Analyzer (Applied Biosystems). All sequenced samples perfectly matched HRM genotyping. In each assay, control samples carrying the three possible sequence variant were used as reference controls.
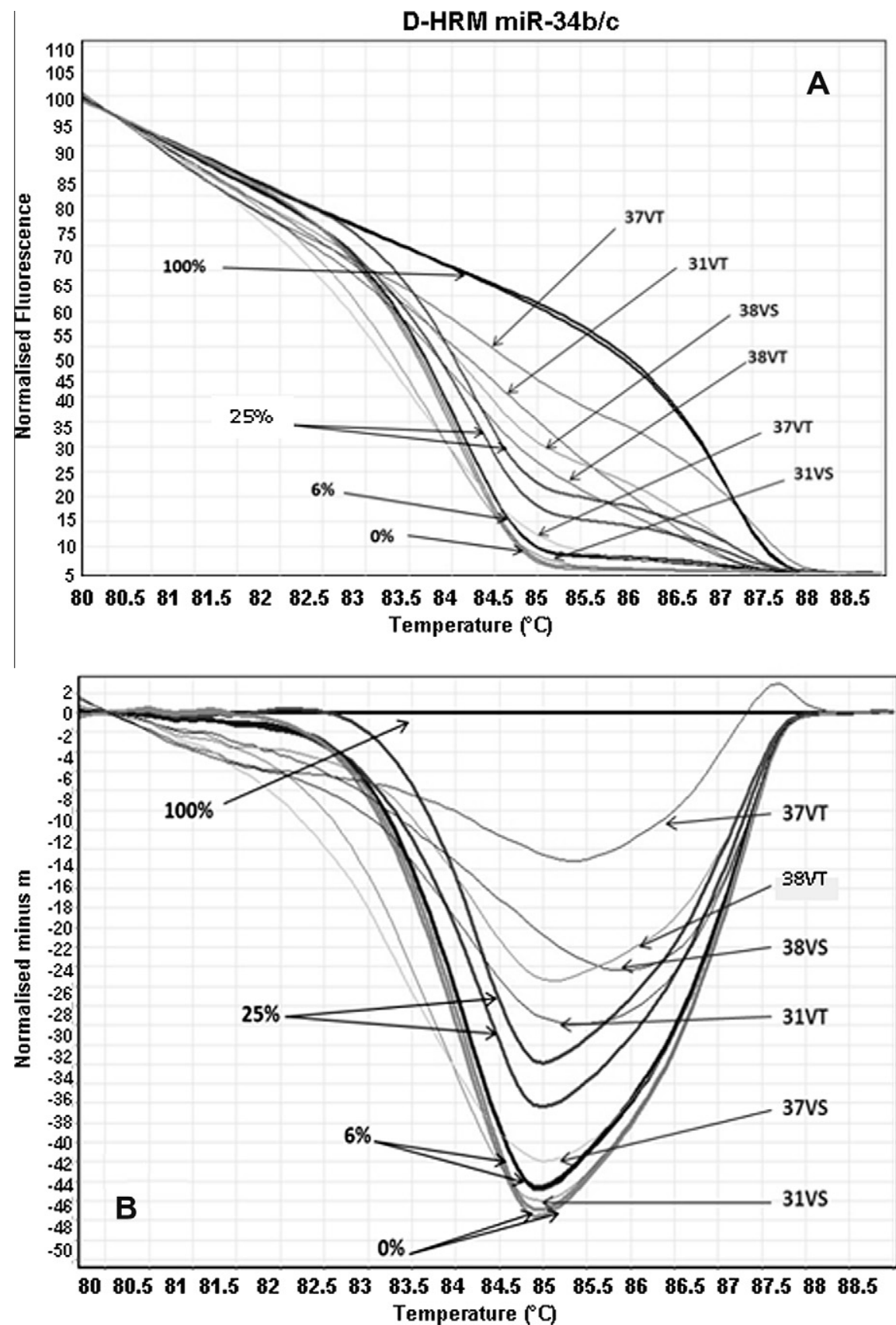

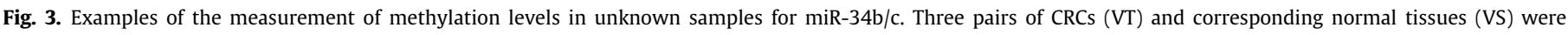

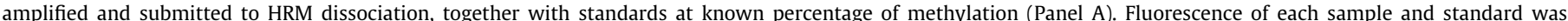

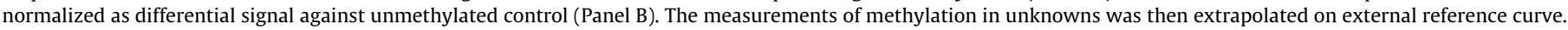
For simplification, we reported in the image only four standard points ( $0 \%, 6 \%, 25 \%$ and $100 \%$ methylation) and a single kinetic for each unknown. 


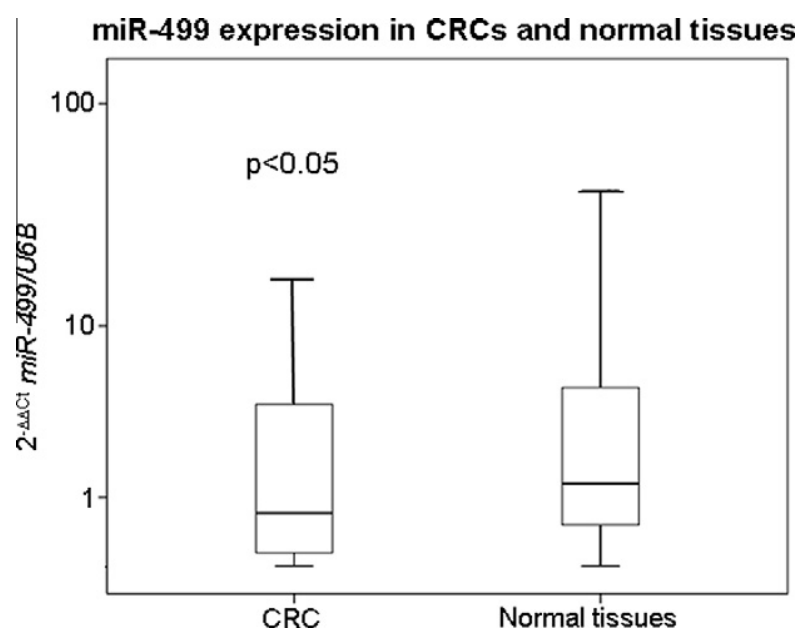

Fig. 4. Expression of miRNA-499 in CRC samples and not affected tissues. Relative real-time RT PCR in $160 \mathrm{CRCs}$ and paired not affected tissues. All experiments were performed in duplicate.

\subsection{Quantitative evaluation of DNA methylation in $m i R-34 b / c$ and miR- 9-1 genes by D-HRM protocol}

The miR-34b and miR-34c genes are respectively located within intron 1 and exon 2 of the same sequence on chromosome 11q23 and the two miRNAs are processed from a single primary transcript $[32,33]$. Hsa-miR-9 is located on chromosome 1q22, at $183 \mathrm{bp}$ of a CpG island [26]. The two miRNAs were demonstrated to be epigenetically regulated [27]. Using Methyl Primer Express v1.0 (www.appliedbiosystems.com) and Pyro Q-CpG v 1.0.9 software (Qiagen) we designed primers that would anneal externally to potentially methylated cytosines (Table 2 ).

We performed analysis of DNA methylation of miR-34b/c, miR9-1 by D-HRM as previously described [28]. For methylation analysis, $500 \mathrm{ng}$ of DNA from samples and standards were treated with sodium bisulfite using the Epitect Bisulfite Kit (Qiagen). Modified DNA was immediately submitted to D-HRM and was stored at $-20^{\circ} \mathrm{C}$. PCR was performed in $12.5 \mu \mathrm{L}$ final volume, containing $1 \times$ Buffer, $3.5 \mathrm{mM} \mathrm{MgCl}$, $800 \mu \mathrm{M}$ dNTPs, $600 \mathrm{nM}$ of each primer, $1.5 \mu \mathrm{M}$ of SYTO9 Dye (Invitrogen, CA, USA) and 1U of Taq Gold Polymerase (Applied Biosystems) and $1 \mu \mathrm{L}$ of DNA treated with bisulfite was amplified. For miR-34b, $2.5 \mathrm{mM} \mathrm{MgCl}_{2}$ was used to increase amplification efficiency. PCR was performed with an initial step at $95^{\circ} \mathrm{C}$ for $10 \mathrm{~min}$, followed by 35 cycles for $30 \mathrm{~s}$ at $95^{\circ} \mathrm{C}, 30 \mathrm{~s}$ at the specific annealing temperature $\left(57^{\circ} \mathrm{C}\right.$ for miR$9-1,55^{\circ} \mathrm{C}$ for $\mathrm{miR}-34 \mathrm{~b} / \mathrm{c}$ ) and $30 \mathrm{~s}$ at $72{ }^{\circ} \mathrm{C}$, final extension at $72{ }^{\circ} \mathrm{C}$ for $20 \mathrm{~min}$. For the HRM, performed on a RotorGene 6000 (Corbett Research, Sydney, Australia), samples were initially maintained for $5 \mathrm{~min}$ at $95^{\circ} \mathrm{C}$, for $1 \mathrm{~min}$ at $40^{\circ} \mathrm{C}$ and then submitted to specific melting profiles.

For each experiment, CpG Genome Universal Methylated and Unmethylated DNA (Chemicon International Inc.) were used as positive ( $100 \%$ methylated) and negative ( $0 \%$ methylated) controls and mutually diluted to generate a 7 points external reference curve with decreasing percentage of DNA methylation (100\%, $50 \%, 25 \%, 12,5 \%, 6,25 \%, 3,12 \%$ and $0 \%$ ).

Melting curves were normalized using the HRM software and a differential profile was then evaluated for each sample by comparing fluorescence at the melting point against the value of fluorescence of the negative control (unmethylated DNA). The values of differential fluorescence $(\Delta F)$ for each point of reference curve were graphically plotted to generate a linear response with standards containing a growing percentage of methylated DNA (Fig. 1 and Fig. 2). The evaluation of methylation levels in unknown samples was calculated by extrapolation of $\Delta F$ on respective external reference curve (Fig. 3). All experiments were performed in duplicate.

\subsection{Statistical analysis}

Statistical analysis ( $T$-Test and Anova) were carried out using the SPSS software package. The associations between miRNA polymorphisms and CRC risk were estimated by odds ratios (OR) and their $95 \%$ confident intervals (95\% CI).

\section{Results}

\subsection{Expression of miR-146a, miR-149, miR-196a2 and miR-499 in cancer tissues and paired not affected tissues}

The relative expression of the four miRNAs was determined in all CRC samples and compared with levels in paired not affected tissues. The expression of miR-146a, miR-149 and $196 a 2$ did not reveal significant differences between normal and affected tissues. In particular, for miR-146a, the median and minimum and maximum were 73.9 (0.04-10297) in the CRC vs. 71.4 (1.1-17559) in the normal tissue; for miR-149 were $0.32(0.0001-89.4)$ in the CRC vs. 1.52 in the normal tissue (0.01-388); for $m i R-196 a 2$ were11.72 (0.04$1176)$ ) in the CRC vs. $8.60(0.01-1097)$ in the normal tissue.

On the contrary, we found a significant decrease $(p<0.05)$ of miR-499 expression in cancers when compared to paired unaffected tissues, as reported in Fig. 4 and Table 3.

\subsection{Allele distribution of miR-146a, miR-149, miR-196a2 and miR-499 genes genotype and miRNA expression}

The application of HRM allowed the correct genotyping to all our samples. In the case of miR-149, miR-196a2 and miR-499 this was obtained by the direct comparison of dissociation profiles that easily discriminated the three possible genotypes. For miR-146a $(C>G)$, the discrimination between CC and GG samples was not obtained in our experimental conditions, whereas heterozygote CRC was easily identified. To discriminate the homozygotes a second PCR was performed in which samples was mixed 1:1 with a standard CC sample, obtaining a GC profile for GG samples, while those with the CC genotype have an unchanged profile.

Examples of dissociation curves for sample screening are reported in Fig. 5.

Table 3

Median (min and max) of miR-499 expression in CRC samples and normal tissue.

\begin{tabular}{|c|c|c|c|c|}
\hline & miR-146a & miR-149 & miR-196a2 & $\mathrm{miR}-499 \times 1000$ \\
\hline CRC & $\begin{array}{l}73.9 \\
(0.04-10,297)\end{array}$ & $\begin{array}{l}0.32 \\
(0.0001-89.4)\end{array}$ & $\begin{array}{l}11.72 \\
(0.04-1176)\end{array}$ & $\begin{array}{l}0.85 \\
(0.01-869.3)\end{array}$ \\
\hline Normal tissue & $\begin{array}{l}71.4 \\
(1.1-17,559)\end{array}$ & $\begin{array}{l}1.52 \\
(0.01-388)\end{array}$ & $\begin{array}{l}8.6 \\
(0.01-1097)\end{array}$ & $\begin{array}{l}1.48 \\
(0.01-1000)\end{array}$ \\
\hline$p$ & 0.295 & 0.578 & 0.128 & 0.05 \\
\hline
\end{tabular}


HRM for genotyping of miRNAs
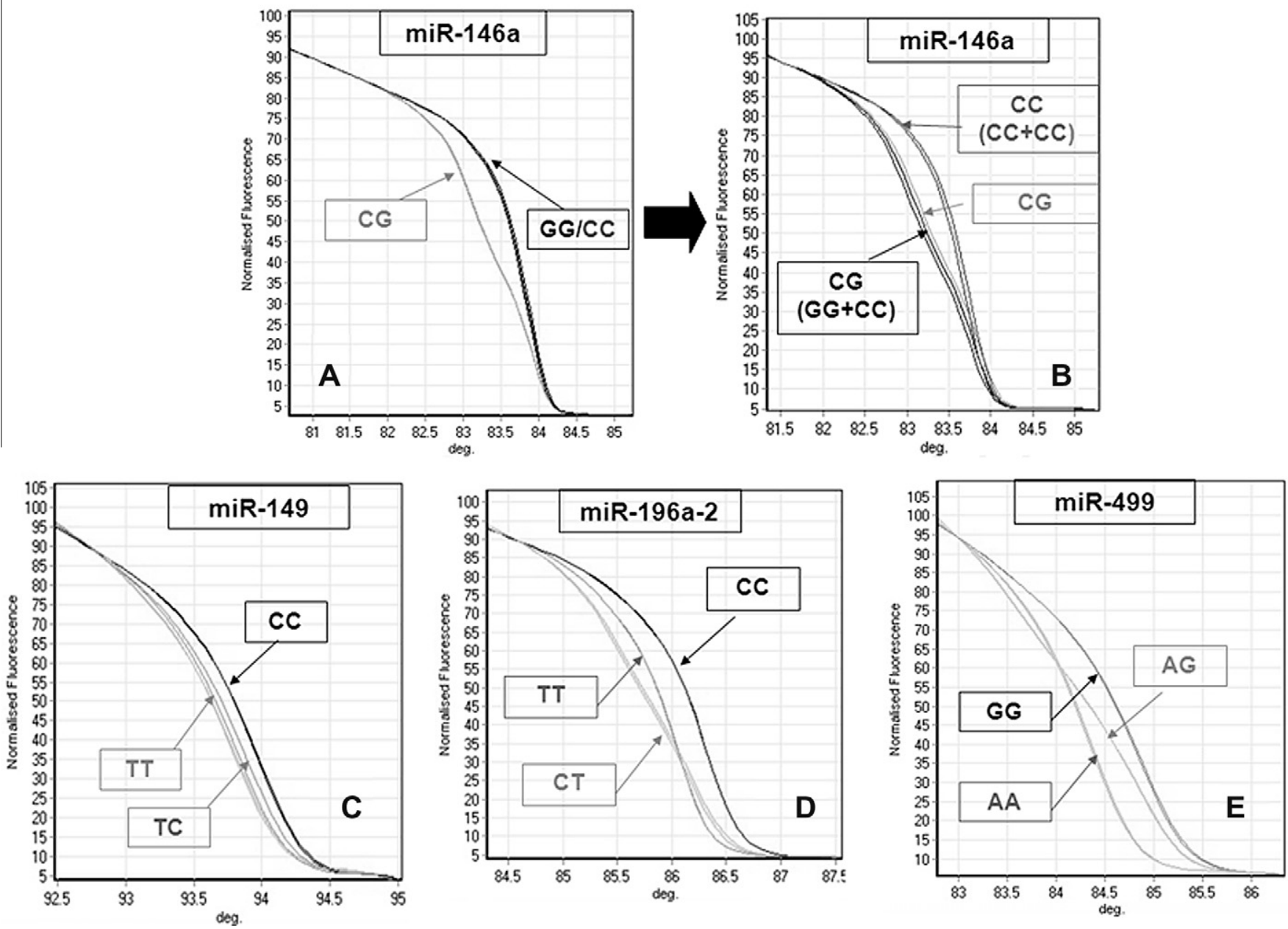

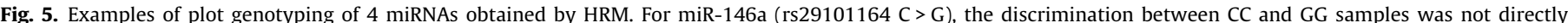

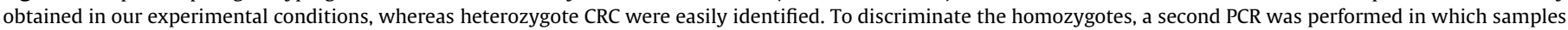

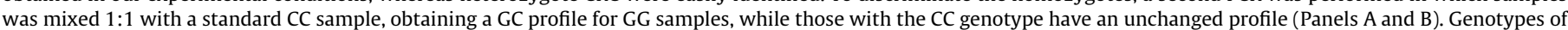

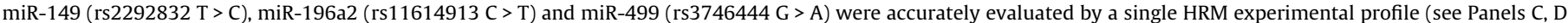
and $\mathrm{E}$, respectively).

Table 4

Allelic frequency and genotype of miRNA in patients affected by CRC $(n=160)$ and control subjects $(n=178)$.

\begin{tabular}{|c|c|c|c|c|c|c|}
\hline $\mathrm{miR}$ & Genotype & CRC $n(\%)$ & Controls $n(\%)$ & OR & $95 \% \mathrm{CI}$ & $p$ \\
\hline miR-146a (rs2910164 C-G) & $\begin{array}{l}\text { GG } \\
\text { CG } \\
\text { CC } \\
{[G] \text { vs. [C] }}\end{array}$ & $\begin{array}{l}86(53.8) \\
57(35.6) \\
17(10.6) \\
\text { [229] vs. [91] }\end{array}$ & $\begin{array}{l}100(56.2) \\
65(36.5) \\
13(7.3) \\
{[265] \text { vs. [91] }}\end{array}$ & $\begin{array}{l}1 \\
1.015 \\
0.681\end{array}$ & $\begin{array}{l}0.64-1.60 \\
0.31-1.48\end{array}$ & $\begin{array}{l}0.521 \\
0.218 \\
0.264\end{array}$ \\
\hline $\begin{array}{l}\text { miR-149 } \\
\text { (rs2292832 C-T) }\end{array}$ & $\begin{array}{l}\text { CC } \\
\text { TC } \\
\text { TT } \\
{[C] \text { vs. [T] }}\end{array}$ & $\begin{array}{l}79(49.4) \\
58(36.2) \\
23(14.4) \\
{[216] \text { vs[104] }}\end{array}$ & $\begin{array}{l}86(48.3) \\
75(42.1) \\
17(9.6) \\
\text { [247] vs. [109] }\end{array}$ & $\begin{array}{l}1 \\
1.176 \\
0.628\end{array}$ & $\begin{array}{l}0.74-1.87 \\
0.31-1.29\end{array}$ & $\begin{array}{l}0.285 \\
0.138 \\
0.278\end{array}$ \\
\hline miR-196a2 (rs11614913 C-T) & $\begin{array}{l}\text { CC } \\
\text { CT } \\
\text { TT } \\
{[C] \text { vs. [T] }}\end{array}$ & $\begin{array}{l}62(38.8) \\
86(53.8) \\
12(7.4) \\
{[210] \text { vs. [110] }}\end{array}$ & $\begin{array}{l}83(46.6) \\
84(47.2) \\
11(6.2) \\
\text { [250] vs. [106] }\end{array}$ & $\begin{array}{l}1 \\
0.721 \\
0.587\end{array}$ & $\begin{array}{l}0.46-1.13 \\
0.25-1.38\end{array}$ & $\begin{array}{l}0.092 \\
0.156 \\
0.073\end{array}$ \\
\hline $\begin{array}{l}\text { miR-499 } \\
\text { (rs3746444 G-A) }\end{array}$ & $\begin{array}{l}\text { AA } \\
\text { AG } \\
\text { GG } \\
{[A] \text { vs. [G] }}\end{array}$ & $\begin{array}{l}93(58.1) \\
32(20.0) \\
35(21.9) \\
{[218] \text { vs. [102] }}\end{array}$ & $\begin{array}{l}105(59.0) \\
56(31.5) \\
17(9.5) \\
{[266] \text { vs. [90] }}\end{array}$ & $\begin{array}{l}1 \\
0.663 \\
2.931\end{array}$ & $\begin{array}{l}0.39-1.11 \\
1.49-5.77\end{array}$ & $\begin{array}{l}0.076 \\
0.001 \\
0.01\end{array}$ \\
\hline
\end{tabular}

Allelic frequencies and genotype distribution of the four SNPs, evaluated by HRM in CRC patients as well as in the group of 178 control subjects are reported in Table 4. All sequenced samples perfectly matched HRM genotyping. For miR-146a, miR-149,
miR-196a2 we did not detect any significant difference in allele distribution between the two groups. Conversely, we were able to demonstrate that for miR-499 showed a significant difference for genotype distribution. In particular GG frequency was signifi- 
miR-499 expression in CRC samples and genotypes

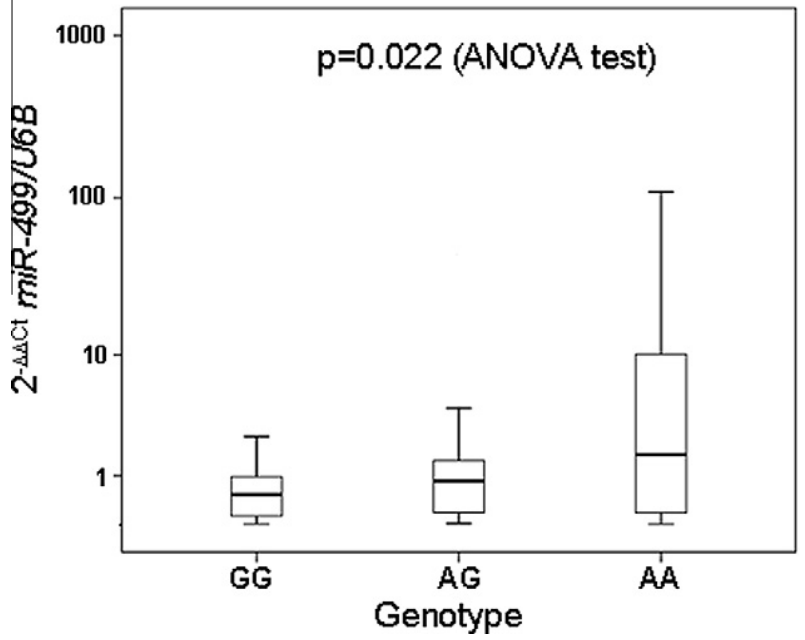

Fig. 6. Expression of miR-499 in CRC samples according genotype. Relative expression of miR-499 in CRC samples stratified according genotype distribution All experiments were performed in duplicate.
Methylation and expression for miR-9-1 in CRC samples

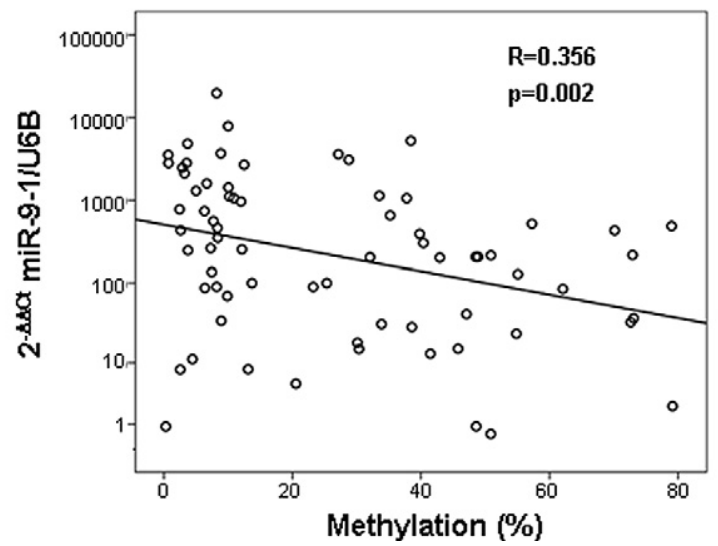

Fig. 9. Relationship between methylation and expression of miR-9-1 in CRC samples. Correlation between methylation density of miR-9-1 and its relative expression.

miR-34b, miR-34c, miR-9-1 expression in CRC samples and normal tissues miR34b

miR-34c

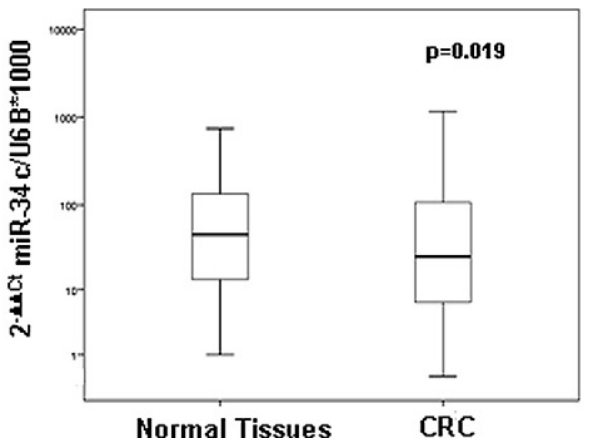

miR-9-1

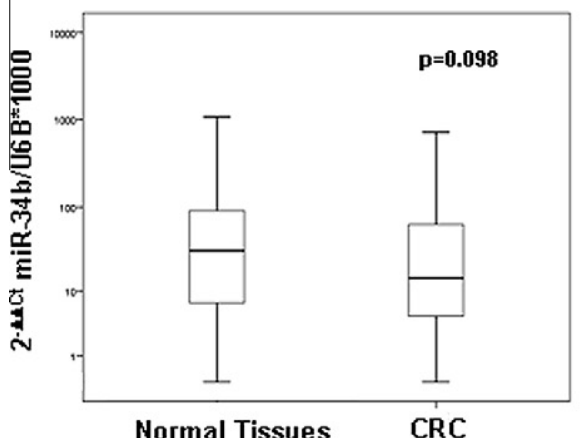

Fig. 7. Expression of miR-34b, miR-34c and miR-9-1 in CRC samples and not affected tissues. Relative real-time RT PCR in 160 CRCs and paired not affected tissues. All experiments were performed in duplicate.

Methylation of miR-34c, miR-9-1 in CRC samples and normal tissues
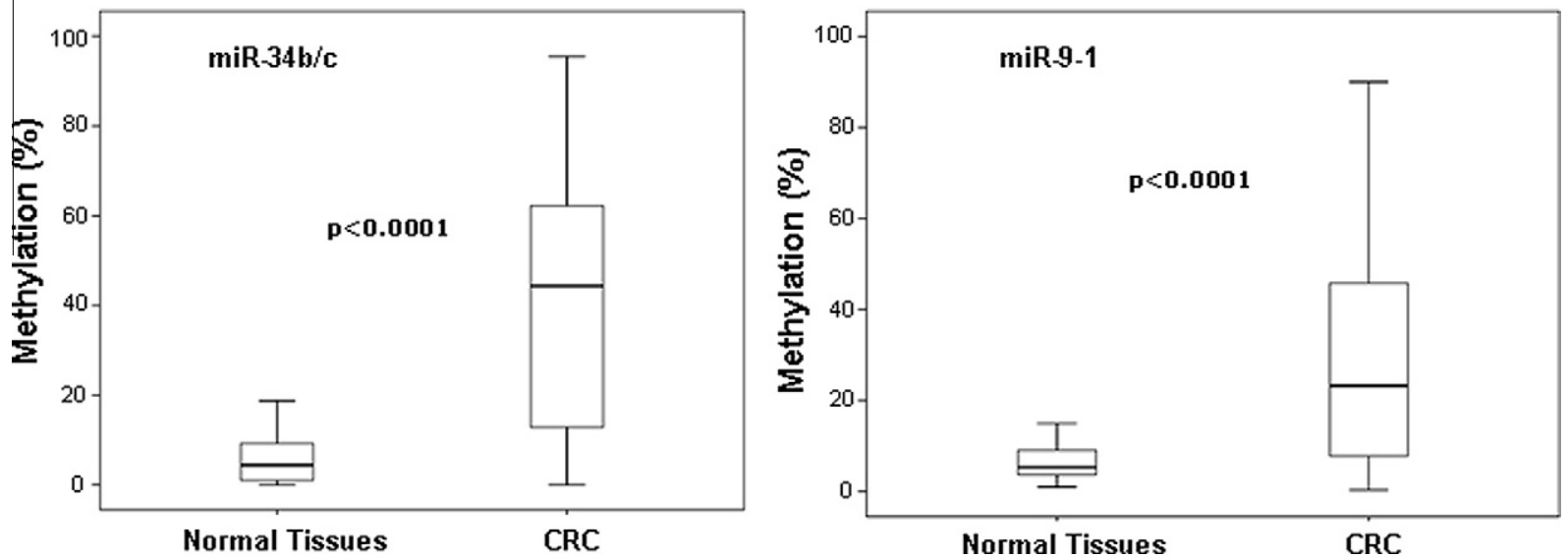

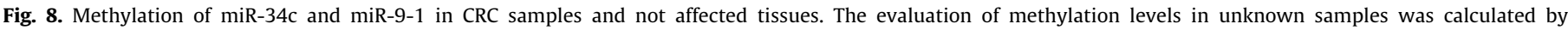
extrapolation of $\Delta F$ on respective external reference curve. All experiments were performed in duplicate. 
cantly higher in CRC patients (21.9\%) in comparison to controls (9.5\%) (GG vs. AA: OR=2.93, 95\% CI 1.49-5.77, $p=0.01$ ) (Table 4). We highlighted a significant difference for miR-499 when we had grouped the GG vs. AAAG ( $p=0.05)$.

To understand the possible influence of SNPs on transcription of related miRNA, we stratified their relative expression according to respective genotype in CRC tissues. We did not find any significant association between genotypes and expression for miR-146a, miR149, and miR-196a2.

On the contrary, miR-499 expression was found significantly associated to its allelic variants, since GG genotype was connected to a reduced expression in comparison to AA samples, whereas AG CRC had and intermediate expression (Anova test, $p=0.022$, Fig. 6). In particular, the data concerning the miR-499 expression associated with the allelic variant showed for genotype GG a median of 0.5 , minimum 0.01 and un maximum of 217.6; for AG $0.8,0.02$ and 101.5; for AA 1.8, 0.01 and 869.3.

Genotype distribution AG vs. GG of miR-499 was not statistically different.

\subsection{Correlation between the expression and methylation status of the promoter region of $\mathrm{miR}-34 \mathrm{~b} / \mathrm{c}$ and $\mathrm{miR}-9-1$}

We evaluated the expression of the 3 miRNAs in the same paired tissues. We highlighted in all cases a reduced expression in CRC that reached the significance for miR-34c $(p=0.019)$ and miR-9-1 ( $p<0.0001)$ (Fig. 7).

Subsequently, the analysis of the level of methylation in CRC and normal paired tissues, obtained by D-HRM, revealed a significant hypermethylation in tumor tissues for both $\mathrm{miR}-34 \mathrm{~b} / \mathrm{c}$ $(p<0.0001)$ and miR-9-1 ( $p<0.0001)$ genes (Fig. 8).

In tumor tissues, the downregulation of their expression and increasing of promoter hypermethylation in these miRNAs, seems to indicate the presence of an epigenetic mechanism underlying their regulation. To confirm this inverse relationship we evaluated their reciprocal linearity. In the case of miR-9-1 we detected a significant $(p=0.002)$ negative relationship, showing that the progressive increase of methylation density correspond to a weak reduction of miRNA expression (Fig. 9).

\section{Discussion}

A great number of studies on miRNA profiling demonstrated that they are distinctively and differentially expressed in cancer tissues as compared with normal adjacent tissues [9]. Genetic and epigenetic mechanisms seem to have an influence on miRNA deregulation in cancers even if these aspects are only partially clarified [34].

A single nucleotide replacement resulting from a mutation or an SNP can be involved in deregulation of miRNA expression [32,3537]. Some studies indicated the association of SNPs in miR-146a, miR-196a2, miR-149 and miR-499 with variable risk in cancers [38,21,39-41].

For this reason, we evaluated the genotype distribution of the four miRNAs in 160 CRC patients. We could not able to identify any association between genotypes and cancer risk for miR-146a, miR-196a2, and miR-149. In addition, using relative RT-PCR we could not find differential expression between normal mucosa and affected tissues for the three miRNAs.

However we demonstrated that the expression of miR-499 is significantly down-regulated in CRC $(p<0.05)$. In addition, the evaluation of genotype distribution of miR-499 in the cancer population revealed a significant difference with healthy subjects. The GG genotype was twofold more frequent $(p<0.01)$ in CRC patients, with an estimated odd risk of 2.9. These results are in agreement with those reported for breast cancer, since the authors had shown that the variant $A>G$ of miR-499 is associated with a significantly increased risk of developing this cancer, with a 1.75 odd risk [38]. Similarly, the G allele was found to be significantly associated with an increased risk of cervical squamous cell carcinoma [42]. Even if both these two published studies suggested a role for the $G$ allele in determining an increased incidence for respective cancers, no functional connection was previously demonstrated to support the relationship between genotype and cancer risk. For this reason, we evaluated the possible influence of genotypes in the regulation of its expression by stratifying miR-499 expression according to its allele distribution. We found that the $G$ allele appears to be associated with a significant decrease in expression, as demonstrated by the progressive reduction of expression in AG and, more clearly, in GG patients $(p=0.02)$. This reduction, mainly associated to the presence of the $G$ allele, could be the reason of the increased risk in GG patients.

We did not find any significant relationship between the expression of single miRNAs and pathological features of CRC patients.

The other aspect investigated in the present study was the relationship between methylation and expression of two miRNA genes that were already known to be epigenetically down-regulated in
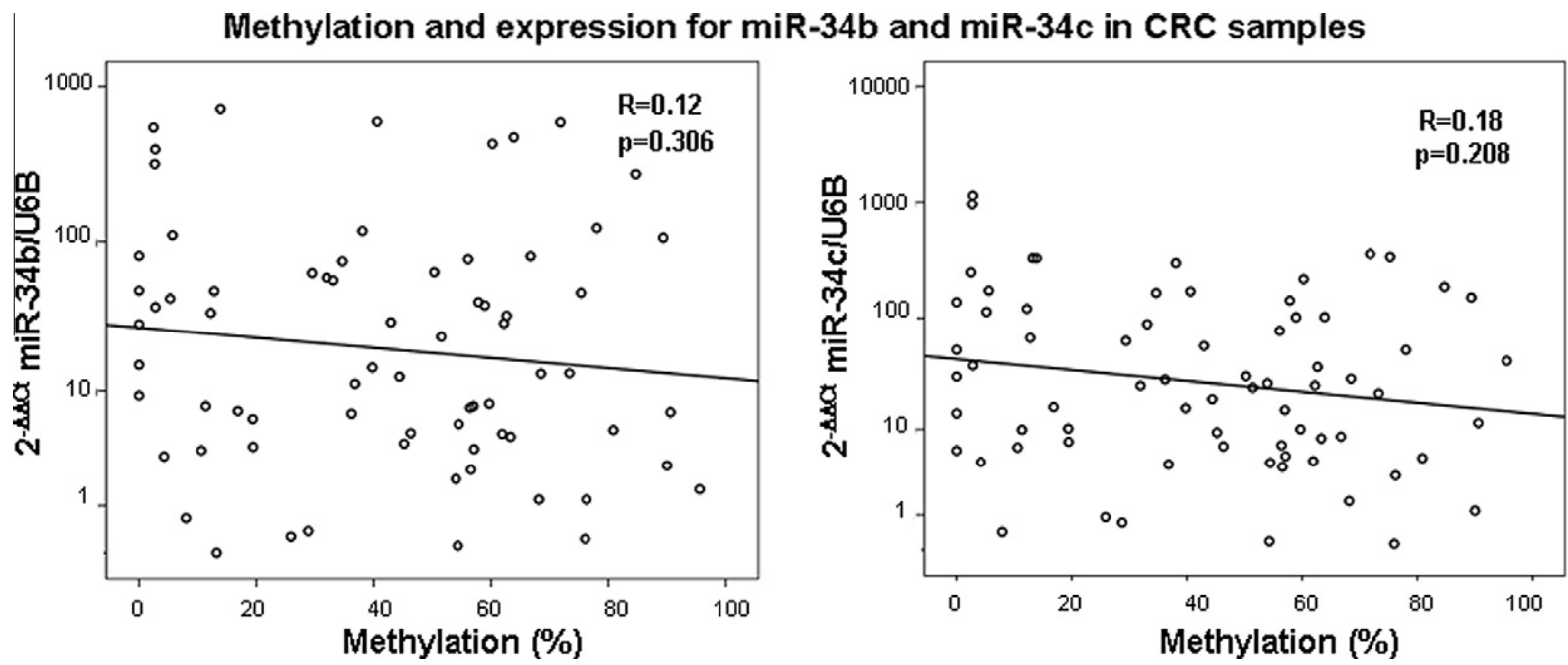

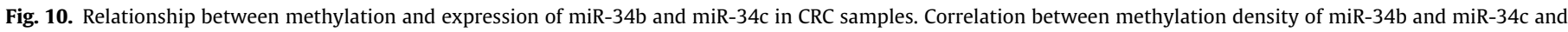
their relative expression. 
CRC $[26,27,43]$. In these previous studies, the epigenetic modulation of $\mathrm{miR}-34 \mathrm{~b} / \mathrm{c}$ and $\mathrm{miR}-9-1$ expression was evaluated by in vitro methods based on functional experiments on cell lines or through qualitative detection of hypermethylated sequences in tumoral DNA. However, the progressive effects of this hypermethylation were not previously studied in vivo, based on the comparison between methylation levels and miRNA expression in CRC samples and paired not affected tissues.

To fulfil our aim, we used a quantitative and accurate method for the estimation of D-HRM, which allows the quantification of methylated sequences referring to an external reference curve generated by reconstituted samples with pre-defined percentage of methylated DNA [28].

The analysis of the methylation level in CRC and normal paired tissues revealed a significant hypermethylation in CRC tumor tissues for both miR-34b/c and miR-9-1 genes.

Regarding miRNA expression, we found no difference between normal tissues and CRC for miR-34b whereas a significant difference was found for miR-34b and miR-9-1.

The final step of the methylation study was performed to evaluate any linear relationship between methylation density and expression for each miRNA. We did not find any significant correlation in the case of miR-34b and miR-34c in CRC (Fig. 10). On the other side, we detected a very low significant relationship between methylation and expression for miR-9-1 that seems to indicate only an hypothetical trend between methylation and expression.

In conclusion the results of our studies seem to indicate that genetic effects connected to SNPs at the level of miRNA genes may have a significant relationship with the expression and clinical features in CRC. On the opposite, methylation seems to have limited significance and impact on miRNA expression; according to our data, we can conclude that methylation cannot be proposed as a potential biomarker in CRC patients.

\section{References}

[1] P.D. Zamore, B. Haley, Science 309 (2005) 1519-1524

[2] R. Duan, C. Pak, P. Jin, Hum. Mol. Genet. 16 (2007) 1124-1131.

[3] M. Wu, N. Jolicoeur, Z. Li, L. Zhang, Y. Fortin, D. L'Abbe, Z. Yu, S.H. Shen, Carcinogenesis 29 (2008) 1710-1716.

[4] E. Lund, S. Guttinger, A. Calado, J.E. Dahlberg, U. Kutai, Science 303 (2004) 9598.

[5] A. Grishok, A.E. Pasquinelli, D. Conte, N. Li, I. Ha, D.L. Baillie, A. Fire, G. Ruvkun, C.C. Mello, Cell 106 (2001) 23-34.

[6] G. Hutvagner, J. McLachlan, A.E. Pasquinelli, E. Balint, T. Tuschl, P.D. Zamore, Science 293 (2001) 834-838.

[7] M. Negrini, M. Ferracin, S. Sabbioni, C.M. Croce, J. Cell Sci. 120 (2007) 18331840.

[8] C.L. Bartels, G.J. Tsongalis, Clin. Chem. 55 (2009) 623-631.

[9] J. Lu, G. Getz, E.A. Miska, E. Alvarez-Saavedra, J. Lamb, D. Peck, A. SweetCordero, B.L. Ebert, R.H. Mak, A.A. Ferrando, J.R. Downing, T. Jacks, H.R. Horvitz, T.R. Golub, Nature 435 (2005) 834-838

[10] N. Rosenfeld, R. Aharonov, E. Meiri, S. Rosenwald, Y. Spector, M. Zepeniuk, H. Benjamin, N. Shabes, S. Tabak, A. Levy, D. Lebanony, Y. Goren, E. Silberschein, N. Targan, A. Ben-Ari, S. Gilad, N. Sion-Vardy, A. Tobar, M. Feinmesser, O. Kharenko, O. Nativ, D. Nass, M. Perelman, A. Yosepovich, B. Shalmon, S. Polak-
Charcon, E. Fridman, A. Avniel, I. Bentwich, Z. Bentwich, D. Cohen, A. Chajut, I. Barshack, Nat. Biotechnol. 26 (2008) 462-469.

[11] I. Bentwich, FEBS Lett. 579 (2005) 5904-5910.

[12] J. Brennecke, A. Stark, R.B. Russel, S.B. Cohen, PloS Biol. 3 (2005) e85.

[13] J. Takamizawa, H. Konishi, K. Yanagisawa, S. Tomida, H. Osada, H. Endoh, T. Harano, Y. Yatabe, M. Nagino, Y. Nimura, T. Mitsudomi, T. Takahashi, Cancer Res. 64 (2004) 3753-3756.

[14] S. Diederichs, D.A. Haber, Cancer Res. 66 (2006) 6097-6104.

[15] W. Yang, T.P. Chendrimada, Q. Wang, M. Higuchi, P.H. Seeburg, R. Shiekhattar, K. Nishikura, Nat. Struct. Mol. Biol. 13 (2006) 13-21.

[16] N. Iwai, H. Narasha, Biochem. Biophys. Res. Commun. 331 (2005) 1438-1444

[17] W. Chen, L.R. Jensen, J. Gecz, J.P. Fryns, C. Moraine, A. de Brouwer, J. Chelly, B. Moser, H. Ropres, A.W. Kuss, Eur. J. Hum. Genet. 15 (2007) 375-378.

[18] J. Yang, F. Zhou, T. Xu, H. Deng, Y.Y. Ge, C. Zhang, J. Li, S.M. Zhuang, Mut. Res. 638 (2008) 205-209.

[19] P. Qi, T. Dou, L. Geng, F. Zhou, X. Gu, H. Wang, C.F. Gao, Hum. Immunol. 71 (2010) 621-626.

[20] I. Catucci, R. Yang, P. Verderio, S. Pizzamiglio, L. Heesen, K. Hemminki, C. Sutter, B. Wappenschmidt, M. Dick, N. Arnold, P. Bugert, D. Niederacher, A. Meind, R.K. Schmutzler, C.C. Bartram, F. Ficarazzi, L. Tizzoni, D. Zaffaroni, S. Manoukian, M. Barile, M.A. Pierotti, P. Radice, B. Burwinkel, P. Peterlongo, Human. Mut. 31 (2010)

[21] T. Tian, Y. Shu, J. Chen, Z. Hu, L. Xu, G. Jin, J. Liang, P. Liu, X. Zhou, R. Miao, H. Ma Y. Chen, H. Shen, Cancer Epidemiol. Biomarkers 18 (2009) 1183-1187.

[22] T. Dou, Q. Wu, X. Chen, J. Ribas, X. Ni, C. Tang, F. Huang, L. Zhou, D. Lu, J. Cancer Res. Clin. Oncol. (2010)

[23] S. Vinci, S. Gelmini, N. Pratesi, S. Conti, F. Malentacchi, L. Simi, M. Pazzagli, C. Orlando, Clin. Chem. Lab. Med. 49 (2011) 2073-2080.

[24] X. Zhou, J. Ruan, G. Wang, W. Zhang, PLoS Comput. Biol. 3 (2007) e37.

[25] H. Yan, A.J. Choi, B.H. Lee, A.H. Ting, PLoS One 6 (2011) e20628.

[26] E. Bandres, X. Agirre, N. Bitarte, N. Ramirez, R. Zarate, J. Roman-Gomez, F. Prosper, J. Garcia-Foncillas, Int. J. Cancer 125 (2009) 2737-2743.

[27] M. Toyota, H. Suzuki, Y. Sasaki, R. Maruyama, K. Imai, Y. Shinomura, T. Tokino, Cancer Res. 68 (2008) 4123-4132.

[28] F. Malentacchi, G. Forni, S. Vinci, C. Orlando, Nucleic Acids Res. 37 (2009) e86

[29] G.M. Borchert, W. Lanier, B.L. Davidson, Nat. Struct. Mol. Biol. 13 (2006) $1097-$ 1101.

[30] D.P. Bartel, Cell 116 (2004) 281-297.

[31] S.A. Krawetz, S. Misener, N.J. Totowa (Eds.), Human Press, 2000, pp. 365-386

[32] L. He, X. He, L.P. Lim, E. de Stanchina, Z. Xuan, Y. Liang, W. Xue, L. Zender, J. Magnus, D. Ridzon, A.L. Jackson, P.S. Linsley, C. Chen, S.W. Lowe, M.A. Cleary, G.J. Hannon, Nature 447 (2007) 1130-1134.

[33] G.T. Bommer, I. Gerin, Y. Feng, A.J. Kaczorowski, R. Kuick, R.E. Love, Y. Zhai, T.J. Giordano, ZS. Qin, B.B. Moore, O.A. MacDougald, K.R. Cho, E.R. Fearon, Curr. Biol. 17 (2007) 1298-1307.

[34] A. Rinaldi, G. Poretti, I. Kwee, E. Zucca, C.V. Catapano, M.G. Tibiletti, F. Bertoni, Leuk. Lymphoma 48 (2007) 410-412.

[35] G.A. Calin, C.D. Dumitru, M. Shimizu, R. Bichi, S. Zupo, E. Noch, H. Aldler, S Rattan, M. Keating, K. Rai, L. Rassenti, T. Kipps, M. Negrini, F. Bullrich, C.M. Croce, Proc. Natl. Acad. Sci. USA 99 (2002) 15524-15529.

[36] B. Brueckner, C. Stresemann, R. Kuner, C. Mund, T. Musch, M. Meister, H. Sültmann, F. Lyko, Cancer Res. 67 (2007) 1419-1423.

[37] C. Slape, H. Hartung, Y.W. Lin, J. Bies, L. Wolff, P.D. Aplan, Cancer Res. 67 (2007) 5148-5155.

[38] Z. Hu, J. Liang, Z. Wang, T. Tian, X. Zhou, J. Chen, R. Miao, Y. Wang, X. Wang, H Shen, Hum. Mutat. 30 (2009) 79-84.

[39] J. Shen, C.B. Ambrosone, R.A. DiCioccio, K. Odunsi, S.B. Lele, H. Zhao, Carcinogenesis 29 (2008) 1963-1966.

[40] T. Xu, Y. Zhu, Q.K. Wei, Y. Yuan, F. Zhou, Y.Y. Ge, J.R. Yang, H. Su, S.M. Zhuang, Carcinogenesis 29 (2008) 2126-2131.

[41] Z. Hu, J. Chen, T. Tian, X. Zhou, H. Gu, L. Xu, Y. Zeng, R. Miao, G. Jin, H. Ma, Y. Chen, H. Shen, J. Clin. Invest. 118 (2008) 2600-2608.

[42] B. Zhou, K. Wang, Y. Wang, M. Xi, Z. Zhang, Y. Song, L. Zhang, Mol. Carcinog. 50 (2011) 499-505

[43] M. Vogt, J. Munding, M. Grüner, S.T. Liffers, B. Verdoodt, J. Hauk, L. Steinstraesser, A. Tannapfel, H. Hermeking, Virchows Arch. 458 (2011) 313322 . 